NASA Technical Memorandum 103211

\title{
Lunar Orbiting Microwave Beam Power System
}

Edgar H. Fay

Sverdrup Technology, Inc.

Lewis Research Center Group

Brook Park, Ohio

and

Ronald C, Cull

National Aeronautics and Space Administration

Lewis Research Center

Cleveland, Ohio

Prepared for the

25th Intersociety Energy Conversion Engineering Conference cosponsored by the AIChE, ANS, SAE, ACS, AIAA, ASME, and IEEE Reno, Nevada, August 12-17, 1990 


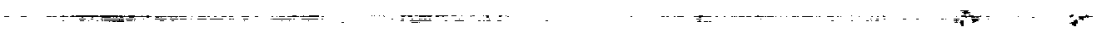




\section{LUNAR ORBITING MICROWAVE BEAM POWER SYSTEM}

\author{
Edgar H. Fay \\ Sverdrup Technology, Inc. \\ Lewis Research Center Group \\ Brook Park, Ohio 44142
}

Ronald C. Cull

NASA Lewis Research Center

Cleveland, Ohio 44135

\section{ABSTRACT}

A microwave beam power system using lunar orbiting solar powered satellite(s) and surface rectenna(s) was investigated as a possible energy source for the moon's surface. The concept has the potential of reduced system mass by placing the power source in orbit. This can greatly reduce and/or eliminate the 14 day energy storage requirement of a lunar surface solar system. Also propellants required to de-orbit to the surface are greatly reduced.

To determine the practicality of the concept and the most important factors, a "zero-th order" feasibility analysis was performed. Three different operational scenarios employing state of the art technology and forecasts for two different sets of advanced technologies were investigated. To reduce the complexity of the problem, salellite(s) were assumed in circular equatorial orbits around the moon, supplying continuous power to a single equatorial base through a fixed horizontal rectenna on the surface.

State of the ant technology yielded specitic masses greater than $2500 \mathrm{~kg} / \mathrm{kw}$, well above projections for surface systems. Using advanced technologies the specific masses are on the order of $100 \mathrm{~kg} / \mathrm{kw}$ which is within the range of projections for surlace nuclear $(20 \mathrm{~kg} / \mathrm{kw})$ and solar systems $(500 \mathrm{~kg} / \mathrm{kw})$. Further studies examining optimization of the scenarios, other lechnologies such lasers transmitters and nuclear sources, and operational issues such as logistics, maintenance and support are being carried out to support the Space Exploration initiative (SEI) to the moon and Mars.

\section{INTRODUCTION}

Operations on the surtace of the moon will depend on a reliable electrical energy source. Providing low cost electrical power on the surface presents signilicant challenge. Energy storage requirements for the 14 day eclipse period make surtace solar power systems heayy. Proposed nuclear power sources have masses highly dependent on power level and may have political and safety concerns. An atternative is to place the the power source in orbit and beam the energy to the surtace. The concept has the potential of lowered system mass by greatly reducing and/or eliminating energy storage and also reducing propellents required to de-orbit to the surface.

Specific masses for surface power plants are projected to range from a low of approximately $20 \mathrm{~kg} / \mathrm{kw}$ for high powerod nuclear up to approximately $500 \mathrm{~kg} / \mathrm{kw}$ for continuous solar power [1]. The objective of this study was to determine, with reasonable technology projections, it a beam power system was competitive with surface power cources.

Multiple approaches including systems using nuclear sourcos and/or laser beaming can be concelved and will be eddressed in luture work. For this study, a simple system where energy is beamed at microwave frequencies from a solar powered satellite(s) to a fixed non-tracking rectenna (an antenna that receives and convens the RF energy to useful dc electrical energy) is investigated. To further reduce the complexity, a single equatorial base and satellite(s) in circular equatorial orbit were assumed.

It is rocognized that more optimum designs are possible and will be explored in future work. Likewise, operational issues such as logistics, installation, maintenance, eic. must be addressed. (See Future Work and Conclusions Section). This first assessment with limited scenarios and technology is thus presented as an initial scoping document.

\section{APPROACH}

Three different scenarios of beaming power from orbit to the lunar surface were investigated. Figure 1 shows the block diagrams for each scenario.

The first scenario, Case 1, consists of a single satellite in obit that transmits power to the surface when in the field of view of the receiver (rectenna). Energy storage is needed on the satellite as well as the ground. Batteries on the satellite provide power for transmission when the satellite is in the eclipse while within the beaming field of view (see figure 2) The energy storage on the surface provides power to the user while the satellite is out of view.

Case 2 is a constellation of satellites providing continuous coverage of the rectenna (see figure 2). Energy storage on the sufface is theretore not necessary. Batteries are provided on each satellite as the energy source for transmission to the surface when that satellite is in the cclipse.

Case 3 is also a constellation of satellites providing continuous coverage, but with the energy storage located only on the surface to provide power to the user when the satellites are in the oclipse. 
Figure 1. System Block Diagrams

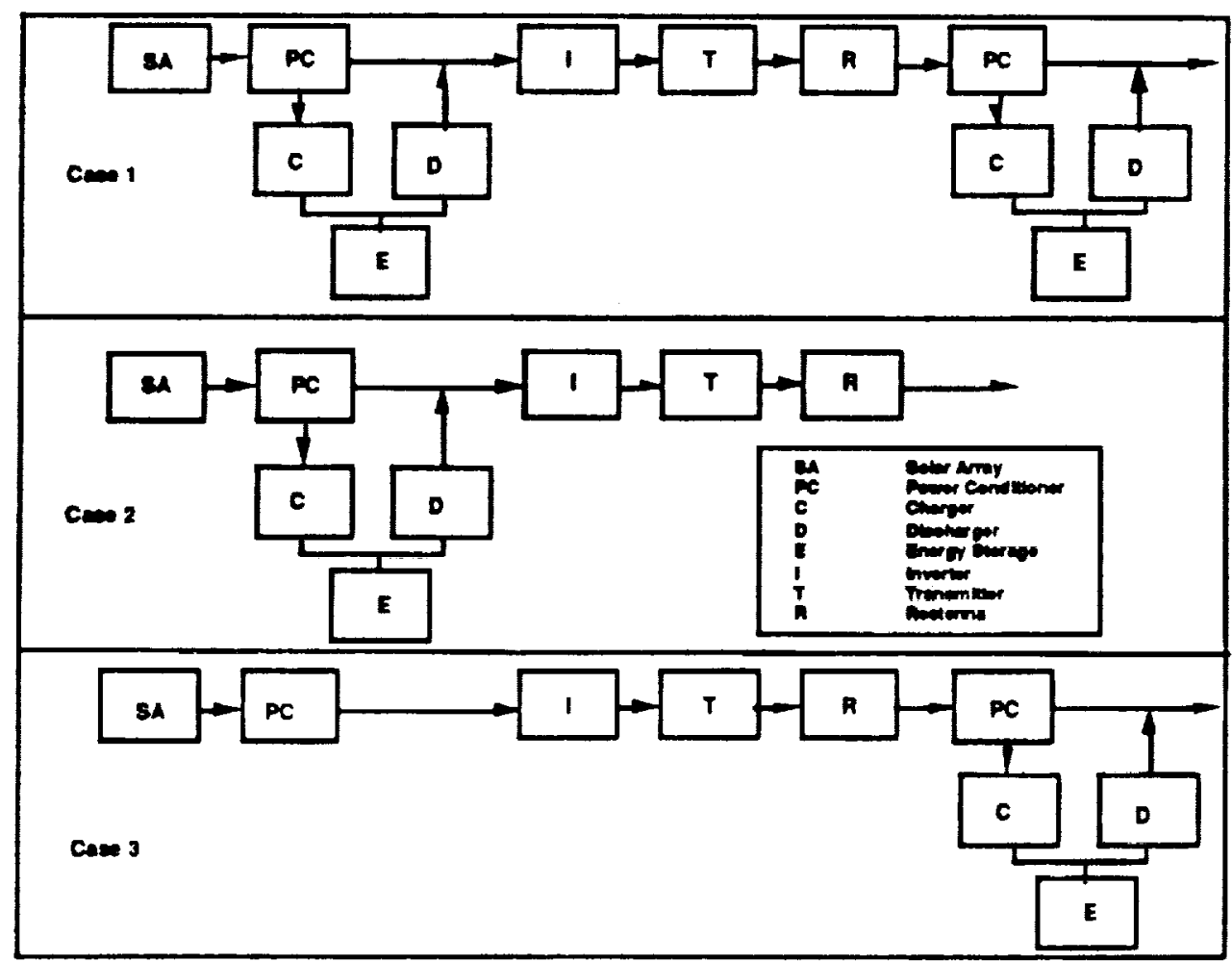

Figure 2. Lunar Obiting Satellites

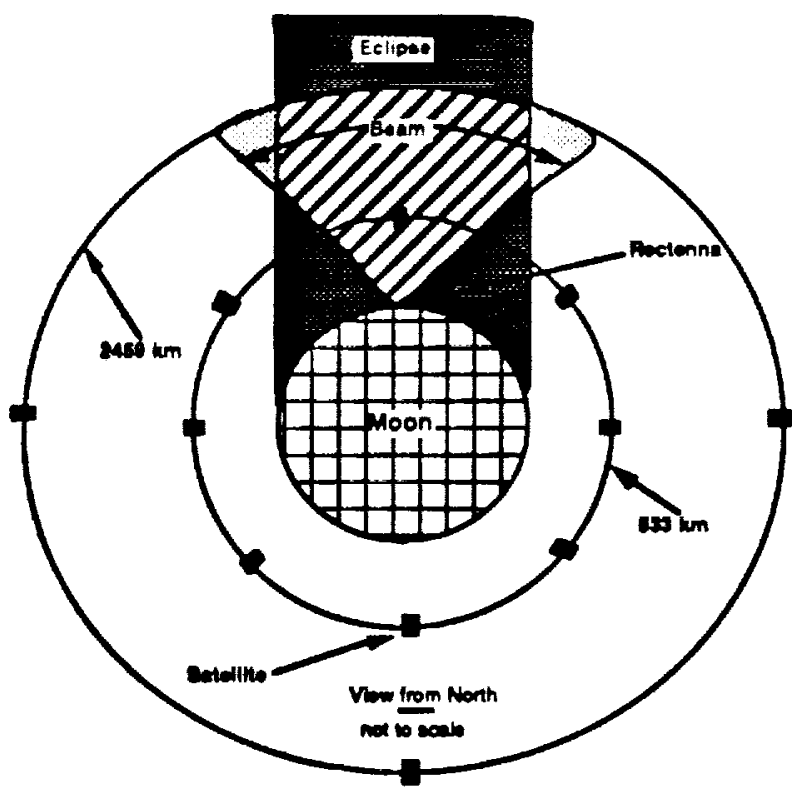

Table 1 indicates the spocific masses and officiencies assumptions for the technologies used in this study. Three levels of technologies were considered:

1. State of Ant (SOA) : This design is similar to the Solar Power Satellite (SPS) studied considerably in the 1970's, but uses SOA components available in the 1990's (see figure 3). The structure uses Space Station Freedom (SSF) trusses. (An "average" specific mass is shown in Table 1, but structure mass is not a linear function of area). The solar array employs single crystal silicon cells, and nickel hydrogen batteries are chosen for energy storage (SSF designs). The nickel hydrogen batteries are sized assuming a depth of discharge (DOD) of $50 \%$. Power Management and Distribution (PMAD) uses components developed for SSF. The thermal management radiators specific masses assume a rejection temperature of $25^{\circ} \mathrm{C}$. Six percent of the masses for solar array drives, batteries, transmitter, and PMAD is added to account for integration masses.

The aluminum slotted waveguide antenna array uses parameters from the SPS [2]. No space qualified microwave tubes of the power level required were known, theretore parameters for $35 \mathrm{GHz}$ terrestrial gyrotron were assumed for the transmitter. (As for all technology lovels, the transmitter efficiencies wore assumed constant for all frequencies. Efficiency is expected to docrease with higher frequency, and this oflect will need to bo lactored in later analyses, but it is expected that the efficiency at higher frequency will be more a function of time and tochnology ovolution than basic physics.)

2. Advanced: Advanced technology represents the evolution of state of the ant technologies to levels believed to be possible by the year 2000 . Advanced lightweight solar cells and batteries are used for the power source. Satellite batteries in this case are sodium suffur operating at 
a temperature of $350^{\circ} \mathrm{C}$ which leads to a correspondingly bwer specific mass for the radiators. The sodium sulfur batteries are sized assuming $50 \%$ DOD. PMAD components are improved and their operating temperalure is also raised, lowering the thermal specific mass. Regenerative Fuel Cells (RFC's) were chosen for surface onergy storage since the charge and discharge cycles are of relatively long durations. The RFC's are sized assuming an $80 \%$ DOD. The transmitter is an improved efficiency tube.

Figure 3 shows schematically a beam power satellite using advanced technology. Four of these Case 2 satellites beaming power at a frequency of $100 \mathrm{GHz}$ from an altitude of $2459 \mathrm{~km}$ provide $1 \mathrm{Mw}$ of continuous power to a user(s) on the surface of the moon. $h$ is of the same general size as SSF. The SSF transverse boom length is $145 \mathrm{~m}$ and its solar array tip-to-tip" length is $72 \mathrm{~m}$. The beam power eatellite's overall dimensions are $148 \times 58 \mathrm{~m}$. As will be discussed later, lower power levels or altitudes would reduce each satellite's size.

Figure 3. Beam Power Satellite Concept (sized using advanced technology)

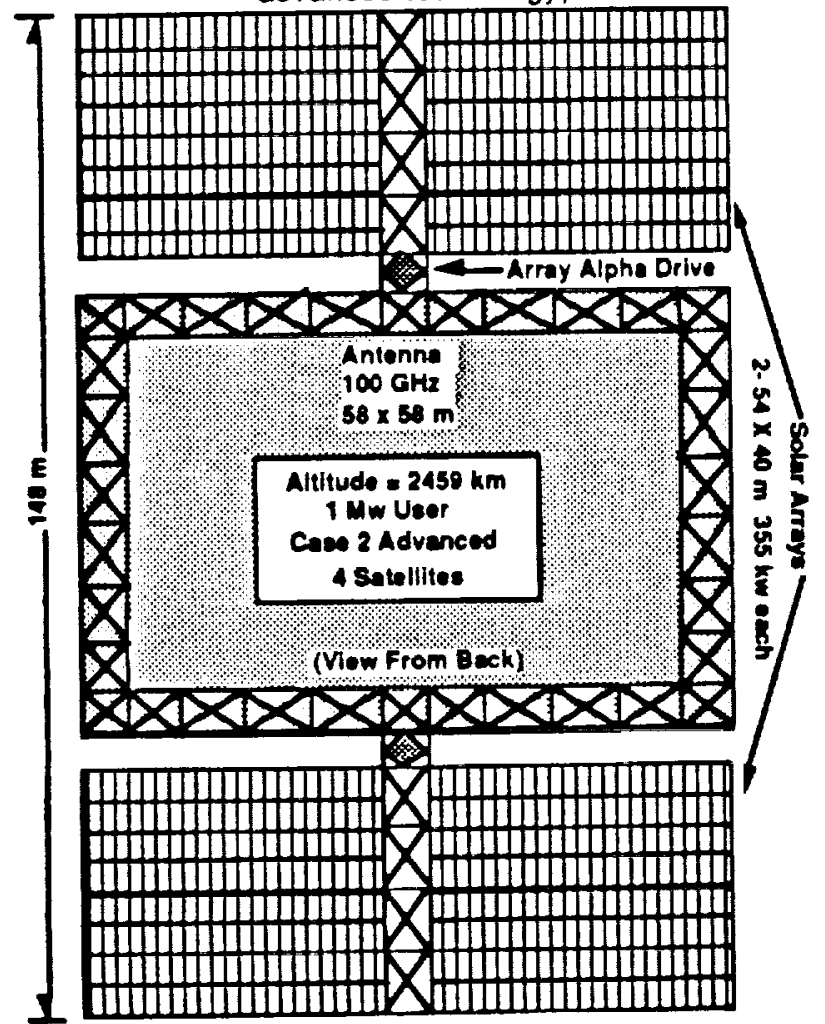

3. Thin Film: Thin film solar cells and solid stale MMIC (Microwave Monolithic Intograted Circuit) devices are presently available for terrestrial applications and projections wero made if space versions of these products could be developed around 2000 . This technology essumes an inflatable structure to support an integrated solar array and antenna, see figure 4 [4]. Amorphous silicon solar cells and RFC's are chosen for power components. The transmitters are solid state MMIC devices in a phased array. This lechnology level is used only for Case 3 since no thin film storage technology was known to exist for the satellites.

Figure 4. Thin Film Technology Beam Power Satellite Concept [4]

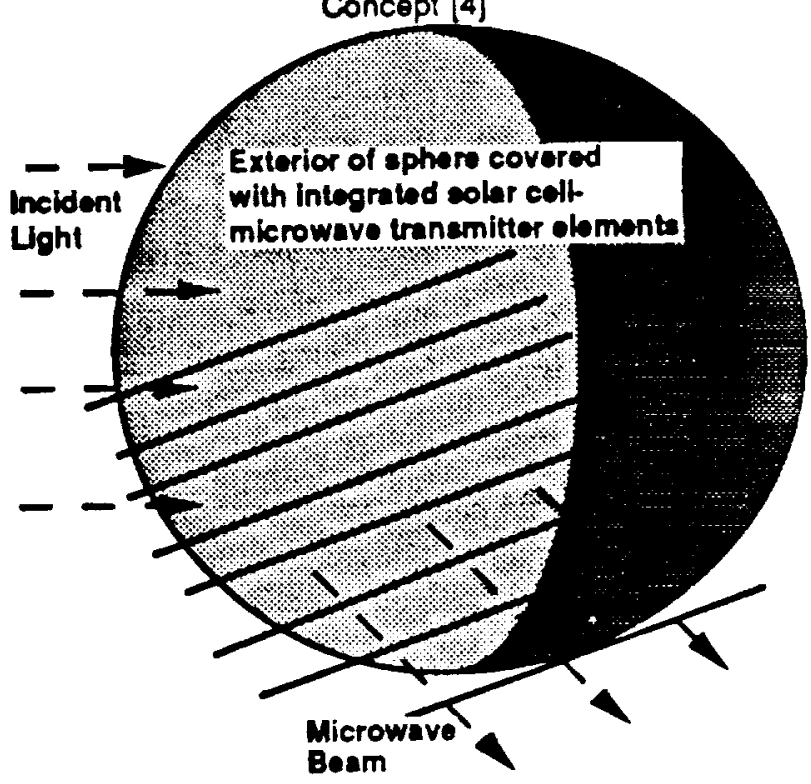

Table 1. Tochnology Performance Parameters

\begin{tabular}{|c|c|c|c|c|c|c|}
\hline & \multicolumn{2}{|c|}{$\frac{1}{6 \pi} x^{2,3}$} & \multicolumn{2}{|c|}{ Trdroneed } & \multicolumn{2}{|c|}{ Thin tilm } \\
\hline Byolem & (notwi) & $x$ & 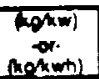 & $*$ & 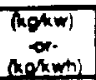 & $x$ \\
\hline 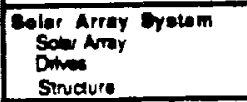 & $\begin{array}{c}20 \\
1 \\
3\end{array}$ & 14 & $\begin{array}{l}3 \\
3 \\
3\end{array}$ & 25 & $\begin{array}{l}7 \\
0 \\
0\end{array}$ & 3 \\
\hline 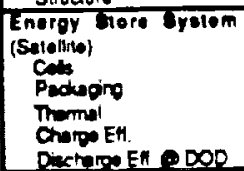 & $\begin{array}{c}21 \\
8 \\
70\end{array}$ & 95 & $\begin{array}{l}10 \\
3 \\
15\end{array}$ & $\begin{array}{r}95 \\
84 \\
\end{array}$ & & \\
\hline 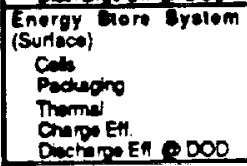 & $\begin{array}{l}21 \\
70\end{array}$ & $\begin{array}{l}\text { is } \\
\text { is }\end{array}$ & $\begin{array}{l}5 \\
5 \\
5\end{array}$ & $\begin{array}{l}10 \\
10\end{array}$ & $\begin{array}{l}.5 \\
.5 \\
5\end{array}$ & $\begin{array}{l}10 \\
10 \\
\end{array}$ \\
\hline 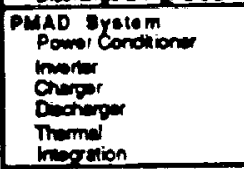 & $\begin{array}{c}5 \\
10 \\
14 \\
14 \\
70 \\
98 \\
\end{array}$ & $\begin{array}{l}97 \\
05 \\
85 \\
06\end{array}$ & $\begin{array}{r}3 \\
2 \\
7 \\
7 \\
15 \\
15 \\
\end{array}$ & $\begin{array}{l}17 \\
06 \\
06\end{array}$ & $\begin{array}{r}1 \\
1 \\
1 \\
1 \\
5 \\
0 \\
\end{array}$ & $\begin{array}{l}98 \\
81 \\
80 \\
08\end{array}$ \\
\hline 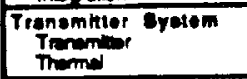 & 5 & 40 & s & 10 & $\begin{array}{r}1 \\
5 \\
\end{array}$ & so \\
\hline 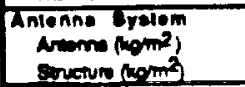 & 4.6 & 100 & $\begin{array}{l}4.6 \\
3 \\
\end{array}$ & 100 & $\begin{array}{l}1 \\
0 \\
\end{array}$ & 100 \\
\hline Arelenne $\mathrm{kgm}^{2} \mathrm{I}$ & 1 & 15 & 1 & 05 & 1 & 45 \\
\hline
\end{tabular}

A spreadsheet was devoloped to pertorm energy balances and calculate the beam power system mass for each scenario and technology lovel. Power components are sized as a function of user powor. End-10-end system masses are cakulated including all support such as thermal management and structural subsystems. By using three different technology levels under three scenarios. the sensitivity of system specilic mass to various subsystem and component performances was obtained. Also, the 
effect of technology on achieving a specific mass competitive with surface options was determined. The modular nature of the spreadsheet can accommodate different power sources (such as a nuclear reactor) and transmission types (such as laser) for future studies.

\section{ASSUMPTIONS}

Transmission frequencies of $2.45,35,100$, and $300 \mathrm{GHz}$ were investigated in this study. The receivers were taken to be placed flat horizontally on the surface with an assumed field of view of $135^{\circ}$.

A near field approximation equation was used to size the antenna and rectenna:

$P_{r} P_{P}=1-\exp \left\{-A_{P} A_{r} /(L R)^{2}\right\}$

Equation 1.

Where:

$$
\begin{aligned}
& \text { R= Separation Distance }(m) \\
& \text { L= Wavelength }(\mathrm{m}) \\
& A_{\mathrm{t}}=\text { Antenna Area }\left(\mathrm{m}^{2}\right) \\
& A_{r}=\text { Rectenna Area }\left(\mathrm{m}^{2}\right) \\
& P_{t}=\text { Transmitted Power }(w) \\
& \text { Pr }=\text { Received Power }(w)
\end{aligned}
$$

When the satellite is directly overhead (i.e. normal to the rectenna), a $15 \%$ space transmission loss was assumed in the calculations (i.e. $P_{r} \mathbb{P}_{t}$ is set equal to 0.85 ). The overall transmitter to rectenna link efticiency will be reduced from the $85 \%$ space transmission efficiency due to oH-normal pointing losses which are a complex function of many parameters such as antenna/rectenna design, orbit paramelers, antenna pointing, elc. A simple numerical integration for an ideal tracking antenna at variable distance yielded a $54 \%$ link etficiency, which was used for all cases. (See Discussion of Results and Future Work sections for further discussion of this assumption.)

The propulsion requirements to land a surface power system from a low lunar orbit will require propellent at least equal to the mass of the power system, affectively doubling the entire system mass. The orbiting portions of the beam power system, of course, requires no de-orbiting capability. To provide a common scale for comparisons with surface-only systems, masses presented are surface equivalent masses (ie orbiting masses are added as half of what they would weigh on the surface).
Orbit parameters calculated for the throe cases are presented in Table 2. The beam times, battery discharge and recharge times, and the number of satellites required for continuous coverage assume a $135^{\circ}$ rectenna field of viow.

For atitudes less than $1336 \mathrm{~km}$, the eclipse time is greater than the beam time (see Fig. 2). Thus, for periods of the lunar night, the satellite will be ontirely in eclipse while within the rectenna field of view. For Case 1 and 2, this means that the satelline batteries' must be sized to provide the entire energy for transmission since the solar arrays will be unable to produce power. The satellite batteries discharge time thus equals beam time. For altitudes at or above $1336 \mathrm{~km}$, the solar array can supply some power directly for transmission even in the middle of the lunar night. The discharge time thus transitions from beam time to oclipse time above $1336 \mathrm{~km}$. Recharge time in both cases is when the salellite is in the sun but not transmitting. The solar array is thus sized to charge the batteries during this recharge time.

For Case 1, the surface batteries provide power when the satellite is out of the rectenna's view. The surtace batteries are recharged during the beam time and discharged during the remainder of the orbit. For Case 3, the surface storage is charged when the salellite is in the sun and transmitting power. During periods of the lunar night when the satellite is eclipsed, the storage provides power for the surface. In all cases, the energy slorage requirements are much less than a surface solar power system.

\section{DISCUSSION OF RESULTS}

Table 3 shows the Cases 1,2 and 3 specific masses for a 1 Mw system at $2.45,35,100$ and $300 \mathrm{GHz}$, using state of the an, advanced and thin film technologies. All specilic masses are shown at their optimum altitude, but no system optimization was performed except trades of antenna and rectenna sizes. The specific masses range from 2920 $\mathrm{kg} / \mathrm{kw}$ using state of the an technology at $2.45 \mathrm{GHz}$ to 84 $\mathrm{kg} / \mathrm{kw}$ using thin film tochnology at $300 \mathrm{GHz}$. For any of the three cases using state of the ant technologies, and Case 1

\begin{tabular}{|c|c|c|c|c|c|c|c|c|}
\hline \multirow{2}{*}{$\begin{array}{l}\text { Antude } \\
\text { (km) }\end{array}$} & \multirow{2}{*}{$\begin{array}{c}\text { Orbl } \\
\text { Periad }\end{array}$} & \multirow{2}{*}{$\begin{array}{c}\text { Eclipee } \\
\text { Tino }\end{array}$} & \multirow{2}{*}{$\begin{array}{l}\text { No. } \\
\text { set'o }\end{array}$} & \multirow{2}{*}{$\begin{array}{l}\text { Dom } \\
\text { Thmo }\end{array}$} & \multicolumn{2}{|c|}{ 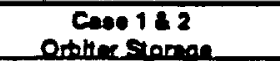 } & \multicolumn{2}{|c|}{$\begin{array}{c}\text { Cwe J } \\
\text { sudinge Storase }\end{array}$} \\
\hline & & & & & $\begin{array}{l}\text { Discharge } \\
\text { Time }\end{array}$ & $\begin{array}{l}\text { Recharge } \\
\text { Time }\end{array}$ & $\begin{array}{l}\text { Diegharge } \\
\text { nim }\end{array}$ & $\begin{array}{l}\text { Rechurge } \\
\text { Tim? }\end{array}$ \\
\hline $\begin{array}{c}90 \\
146 \\
211 \\
374 \\
533 \\
100 \\
1336 \\
2450 \\
10566\end{array}$ & $\begin{array}{l}1.05 \\
2.04 \\
2.14 \\
2.42 \\
2.70 \\
3.38 \\
4.31 \\
6.70 \\
34\end{array}$ & $\begin{array}{l}.78 \\
.76 \\
.75 \\
.74 \\
.75 \\
.77 \\
.82 \\
.82 \\
1.53\end{array}$ & $\begin{array}{l}30 \\
20 \\
15 \\
10 \\
8 \\
6 \\
5 \\
4 \\
3\end{array}$ & $\begin{array}{r}.07 \\
.10 \\
.14 \\
24 \\
.34 \\
.56 \\
.05 \\
1.7 \\
11.3\end{array}$ & $\begin{array}{r}.07 \\
.10 \\
.14 \\
.24 \\
.34 \\
.56 \\
.82 \\
.02 \\
1.53\end{array}$ & $\begin{array}{l}1.17 \\
1.20 \\
1.30 \\
1.68 \\
1.05 \\
2.61 \\
3.45 \\
5.08 \\
22.7\end{array}$ & $\begin{array}{l}268 \\
251 \\
235 \\
206 \\
186 \\
153 \\
128 \\
91 \\
30\end{array}$ & $\begin{array}{l}403 \\
420 \\
436 \\
465 \\
485 \\
518 \\
543 \\
580 \\
641\end{array}$ \\
\hline
\end{tabular}
advanced, the resuling specific masses are greater than the surface solar option. Therefore, they will not be discussed further.

Table 2. Orbit Parameters all tImos in hours 
Table 3. Specific Mass Resulhs

\begin{tabular}{|c|c|c|c|c|c|c|c|}
\hline $\begin{array}{c}\text { Froqueney } \\
\text { (GHz) }\end{array}$ & & & & & & aselky & \\
\hline $\begin{array}{c}2.45 \\
35 \\
100 \\
300\end{array}$ & $\begin{array}{l}50 A \\
2920 \\
2482 \\
2460 \\
2452\end{array}$ & $\begin{array}{l}\text { Ady } \\
887 \\
611 \\
589 \\
582\end{array}$ & $\begin{array}{l}30 A \\
2474 \\
1448 \\
1328 \\
1269\end{array}$ & $\begin{array}{l}\text { Adv } \\
001 \\
387 \\
327 \\
282\end{array}$ & $\begin{array}{l}84 \\
8863 \\
3043 \\
2606 \\
2447\end{array}$ & $\begin{array}{l}A d v \\
1286 \\
415 \\
295 \\
200\end{array}$ & $\begin{array}{c}\text { Thin Flim } \\
367 \\
170 \\
107 \\
84\end{array}$ \\
\hline
\end{tabular}

For Case 3, the efficiencles assumed for the thin film devices represent todays terrestrial versions (and should go higher with time) but specific masses for the comportionis quoted and structures designed with them have a large error band since there are still many unknowns. There is a higher confidence value placed on the performance of the advanced technologies since it is an extension of large space structure design such as SSF and a more established space qualitied technology database exists.

One of the first parameters of interest is transmission frequency. Figure 5 shows the antenna/rectenna areas, calculated using equation 1., versus altitude for $2.45,35$, 100 and $300 \mathrm{GHz}$. Altitude and frequency have a large effect on antenna/rectenna areas and tend to drive the satellites to a lower orbit to minimize the antenna/rectenna size and mass.

Figure 5. Antenna/Rectenna Area vs Altitude

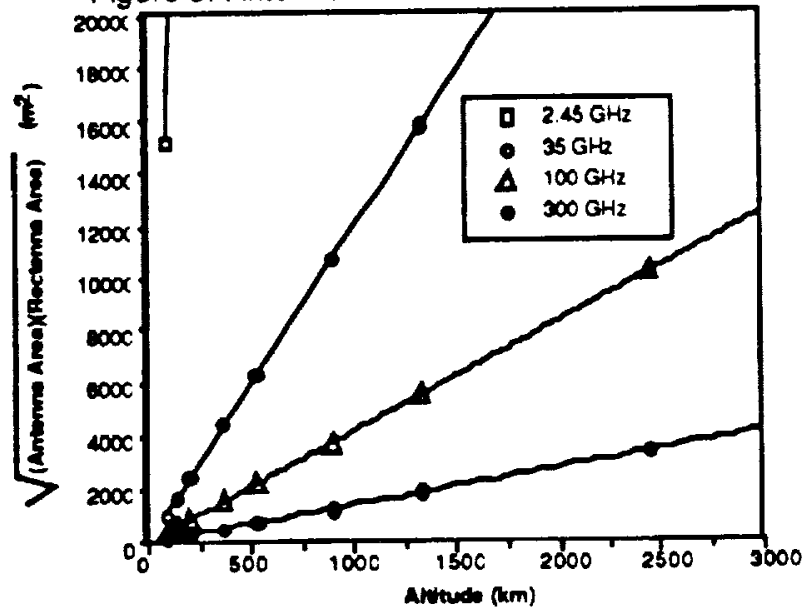

This effect of trequency can be seen in figure 6 which shows the specific mass of the beam power system versus frequency using advanced and thin film technologies. The beam power system is sized to deliver $1 \mathrm{Mw}$ of continuous power at the surface. The points plotted here relate to the alitude yielding the lowest system mass. At $2.45 \mathrm{GHz}$ the antenna and rectenna masses are so large that they dominate the total system mass. Overall though, the transmission system does not contribute significantly to the system mass at greater than $35 \mathrm{GHz}$ and little is gained a frequencies above $100 \mathrm{GHz}$ for the cases investigated.

The small dependence on transmission system above 100 $\mathrm{GHz}$ reduces the importance of the $54 \%$ efticiency assumption used for the transmission link. If the actual link efficiency is less, the antenna/rectenna sizes can be increased without major eflect on tolal mass (assuming larger sizes can be buit).
The system mass is composed of power dependent components (which scale linearly with power lovel), and the entenna/rectenna which are nol a tunction of power, but of attitude and frequency. The antenna/rectenna will contribute most of the mass to very small power systems.

As power lovel is increased, the antenna/rectenna sizes remain constant and further mass increases come only from the power system. The total system specilic mass thus will decrease with increasing power.

One Mw continuous supplied power at $100 \mathrm{GHz}$ transmission frequency will be used in further discussions of Case 2 Advanced, Case 3 Advanced and Case 3 Thin Film. The specitic mass results can be scaled (to a first order) to other power levels and frequencies by proportional increases (decrease) of the plotted antenna/rectenna specific mass for decreased (increased) power and/or frequency.

Figure 6. Specilic Mass Advanced \& Thin Film Technology

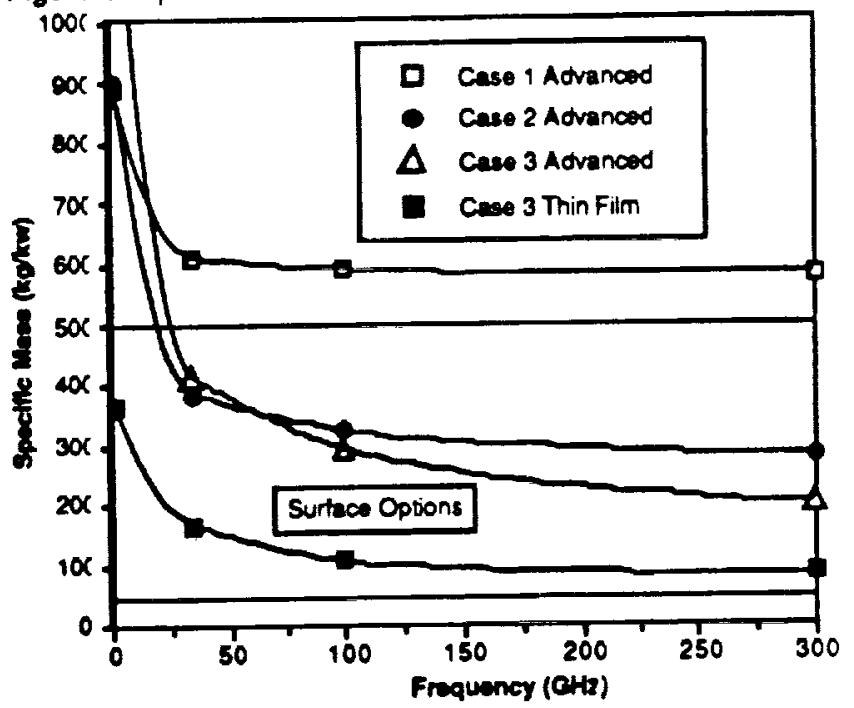

Figure 7 shows the specific mass of the beam power system under Case 2 sconario using advanced technology. The PMAD and transmitter on each satellite are sized to provide the total continuous power to the user. As seen previously from Table 2, the beam time increases with attitude which loads to a lower number of satellites required. Thus, as the altitude increases, the reduction in sefollites, in lurn, decreases the total satellite PMAD and transmitter mass. 
The energy storage mass increases due to an increase in discharge time. Notice that the storage mass is increasing up to $1336 \mathrm{~km}$, decreases up to $2459 \mathrm{~km}$, then continues to increase as the altitude increases. At $1336 \mathrm{~km}$, the discharge time changes from the beam time to the eclipse time which causes the storage mass trend to become discontinuous and decrease due to the array being able to provide some power during transmission. Above $2459 \mathrm{~km}$, the storage mass continues to increase from an increase in eclipse time. (If the total discharge time from the constellation is plotted versus attitude, the trends will be the same as the storage mass shown in figure 7 ).

The arrays and storage are not a function of the number of satellites but rather the total energy needed from the entire constellation. On the other hand, the antenna noeds to be replicated on each satellite. Even so, the antenna (and rectenna) are not significant mass drivers until altitudes bove $1000 \mathrm{~km}$.

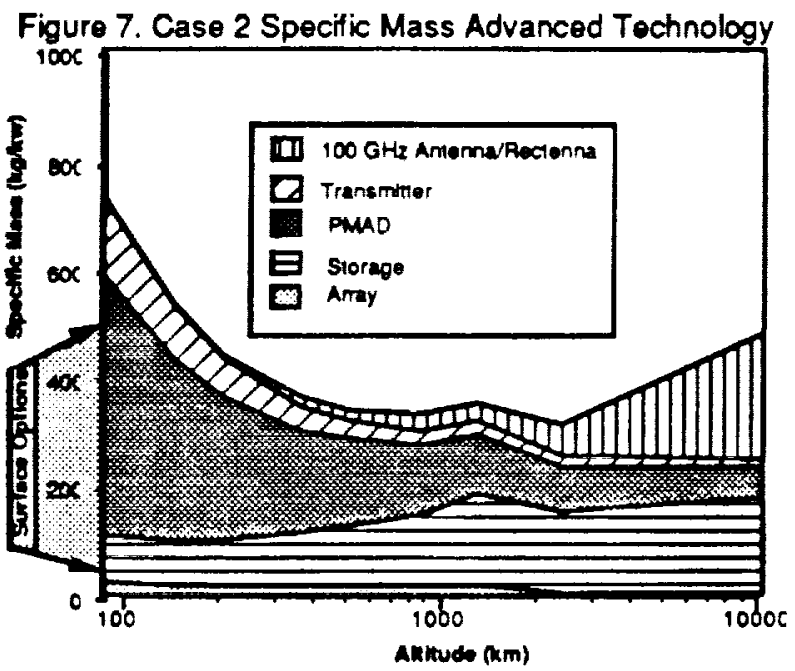

The specific mass is plotted for Case 3 advanced technology in figure 8. All elements except the antenna/rectenna decrease with altitude due to the increasing view time with the salellite in the sun. The RFC's mass is decreasing with altitude because of the

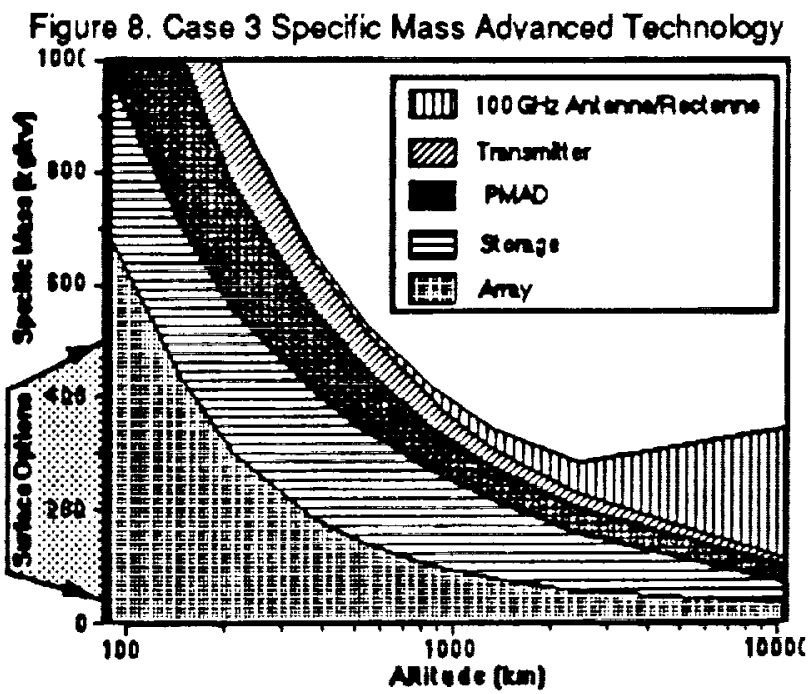

corresponding decreasing discharge time. The satellite and surface PMAD and the transmitter masses decrease as the altitude increases due to a lower peak power resulting from increasing transmission times. The antenna/rectenna do not contribute signilicantly below $2500 \mathrm{~km}$.

Plotted in figure 9 is the specific mass using the thin film lechnologies at $100 \mathrm{GHz}$. The mass trends of the thin film technologies are the same as in the advanced technology cese. However, the array has become much less of a mass driver than the energy storage by virtue of its bwer specitic mass. The energy storage total mass has not decreased since in assumes the same RFC's as in the advanced tochnology. The transmitter mass is larger than in the advanced lechnology due to the thermal support arising from the assumed $50 \%$ efficiency. Finally, by using inflatable structures for the integrated thin film antenna and colar array, the significance of antenna weight has been further reduced.

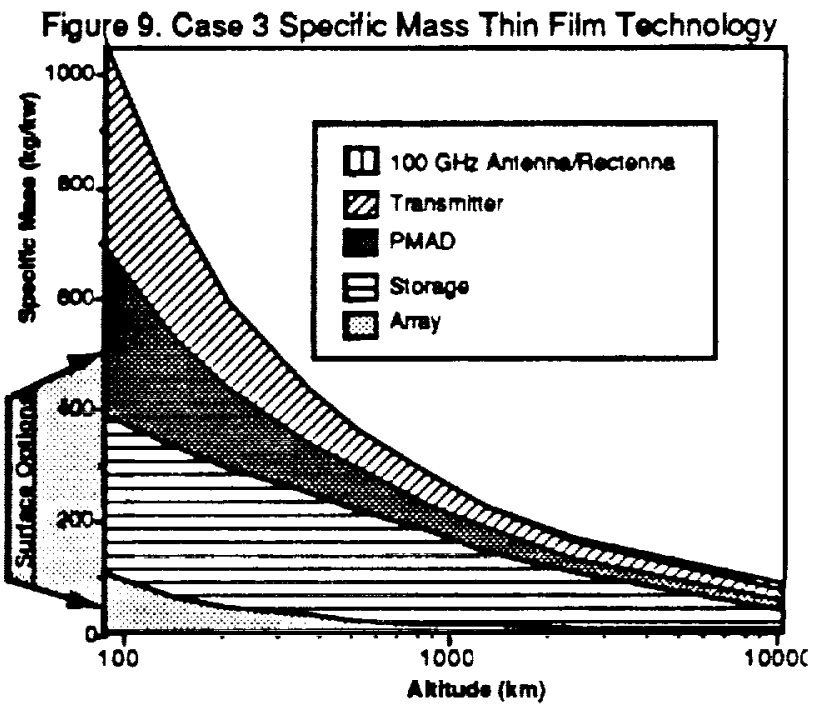

FUTURE WORK

In all scenarios of interest, storage and PMAD are the dominate mass. To reduce the system specific mass whithout using very optimistic projections for energy storage, means must be doveloped to funther reduce or climinate the energy storage. One method of reducing the energy storage requirements is to place the satellites into inclined olliptical orbits such that they experience shorter oclipses. High enough inclination could oliminate the need tor surface or orbiting energy storage except for periods of earth eclipse (possibly twice a year) and for emergency back-up.

The antenna and/or rectenna could be articulated with a large gimballed mechanism to point directly at the satellite, capturing more incident RF energy and allowing inclined orbits. The increased transmission efficiency would resuth in lower power dependent masses. Additionally, the field of view would be greatly increased resulting in fewer satellites at a given altitude. Further, the beam time to 
cclipse ratio would bo greatly increased resulting in reduced storage requirements. More analysis needs to be performed to understand the issues involved and to determine the utimate payback.

The antenna and rectenna masses dominate the total system at $2.45 \mathrm{GHz}$, leading to the conclusion that higher frequencies are necessary to lower the system mass. For the cases investigated other considerations such as structural needs of the ability to articulate the antenna/rectenna may also justity the higher frequencies.

Conversely, transmitter efficiency versus frequency must be determined. The transmitter can become a major mass driver if the actual officiencies are considerably less than essumed for this study. The mass could increase due to the larger thermal management needed to reject the increased waste energy. Also, bwer efficiency would have a ripple effect through the entire system by increasing the size of the power dependent masses.

High magnetic fields are needed to operate gyrotron fube microwave transmitters. These high magnetic field levels require that for high frequencies, the gyrotron operates either with superconducting magnets, or at harmonics of the resonant frequency. Operation at a harmonic frequency reduces the required magnetic field by a factor approximately equal to the harmonic number, thereby overcoming the need for superconducting magnets. Beyond the second harmonic, however, the efliciency rapidly degrades [5]. Further analysis needs to be done to determine the mass of the thermal rejection system needed to cool the superconducting magnet to cryo-level temperatures.

In this study several assumptions were made that will need to be addressed in future studies. The actual transmitter/rectenna link efficiency should be calculated, athough it was seen that the antenna/rectenna size was not the mass driver in the scenarios investigated. Parameters such as antenna size and array/storage size though should be traded to optimize system pertormance. Operations issues such as installation, maintenance, station keeping and reliability must be considered. Also, the assumption of a single base, located on the equator, may not be realistic and inclined orbits may need be investigated to accommodate high latitude base locations. The only figure of merit truly considered in this study was specilic mass. Other criteria such as volume, cost and operation issues must be addressed.

\section{CONCLUSIONS}

The energy storage for the 14 day "lunar night" is the major mass driver tor a lunar surface power system with a solar source. Using an orbiting beam power system, the eclipse times are greatly reduced, and therefore, the energy storage mass is greatly reduced.

To realize this gain though, requires the additional elements of a beam power transmission link consisting of satellite(s), structure, PMAD, transmitter, antenna, microwave link and rectenna. These add not only mass but also efficiency losses to the power train that must be made up with additional solar array size. The net mass change will depend on many factors.

The study has demenstrated that the specific mass of a beam power under certain technology and scenario essumptions falls botween surface solar and nuclear power options (io 20 to $500 \mathrm{~kg} / \mathrm{kw}$ ). More favorable system scenarios then those examined and system optimization could bring down the specitic mass further. However, more work needs to be accomplished to understand the ctual teasibility of microwave beam transmission.

In order to consider a beam power system as a lunar power option, advanced and/or thin film technologies are required. The costs and risks involved in dovoloping these technologies needs to be examined. Likewise, operational issues such as satellite control, station koeping, installation and maintenance need to be addressed.

Presently we are commencing a study to determine the teasibility of beam power transmission concepts for the moon and mars as part of the Space Exploration Initiative (SEI). The system level studies described here will be expanded to include other options such as laser transmission and nuclear power sources. Also, more intensive investigations into the pertormances, costs. risks and developments of the technologies needed in a beam power transmission system will be accomplished with particular attention paid to system integration issues.

\section{REFERENCES}

[1] R.J. Sovie, Nuclear Power Systems for Lunar and Mars Exploration". to be published in 41 st International Astronautical Conference.

(2) W.C. Brown, "Design Study for a Ground Microwave Power Transmission System For Use With a High Atitude Powered Platform," NASA Wallops Flight Center, Contract NAS 6-3200, Pp. 2.15-2.23.

[3] Nils J. Diaz, of al., "UTVRs for Space Power Generation". Proc. Space Power Vol. 8 Numbers 1/2, pp. 230, 1989

[4] G.A. Landis and R.C. Cull, "Applications of Thin Film Tochnology Toward a Low-Mass Solar Power Satellite*, to be published in Vision-21:Space Procoedings at Travel for the Next Millonnium.

[5] Kenwyn Long. NASA Lowis Research Conter, personal conversation, April 19, 1990.

This work was supported by the NASA Lewis Research Conter under contract NAS3-25266 with Ronald C. Cull as monitor. 


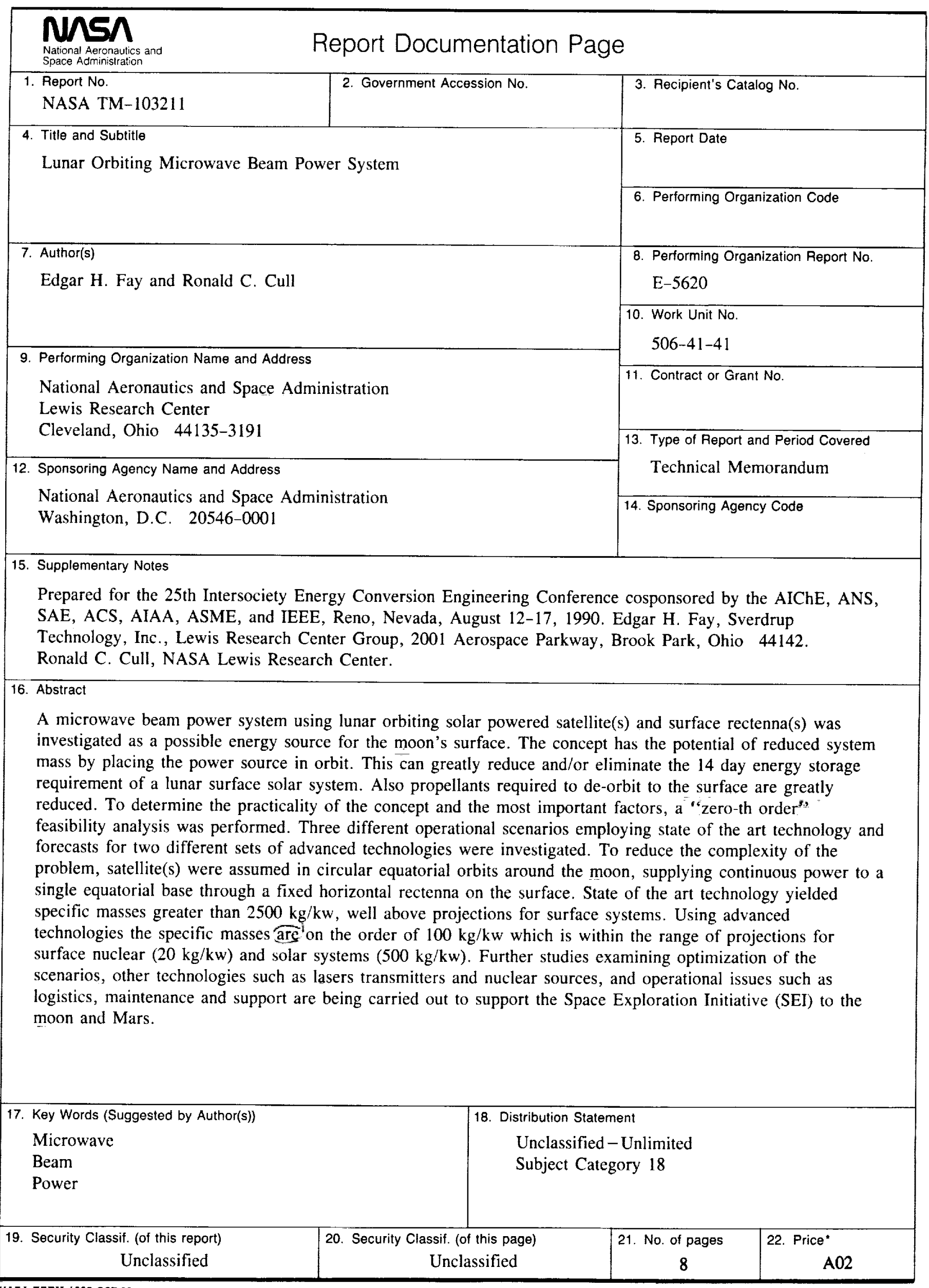

